\title{
Use of New Rangeland Seedings by Black-tailed Jackrabbits
}

\author{
J. KENT MCADOO, WILLIAM S. LONGLAND, GREG J. CLUFF, AND DONALD A. KLEBENOW
}

\begin{abstract}
Black-tailed jackrabbit (Lepus californicus) use of 2 new rangeland seedings in northern and central Nevada was determined by fecal pellet counts for the first growing seasons following seeding establishment. Jackrabbit use was an inverse function of seeding size (as indicated by distance from seeding edges to midpoints). Use was uniformly high for a small (50-ha) seeding from its edge to its midpoint. A larger (400-ha) seeding received significantly higher use at the edge than at $100-\mathrm{m}$ intervals extending to the $400-\mathrm{m}$ midpoint. Jackrabbit use of seedings was higher during late summer than during early summer. Jackrabbit abundance was significantly higher in sagebrush habitat adjacent to a new seeding than in similar habitat away from the seeding. Our results suggest that forage availability is a factor influencing use of seedings, and predation risk may also be involved.
\end{abstract}

Key Words: Lepus californicus, seedings, forage availability, predation risk, optimal foraging theory

Authors are former wildlife research associate, University of Nevada, Reno, currently environmentalist with Freeport-McMoRan Gold Co., Mtn. City Star Rt., Elko, Nev. 89801 ; research assistant, University of California, Riverside; plant breeder, WI Research, Bakersfield, Calif;; and professor, University of Nevada, Reno.

This study is a contribution of the USDA, Agricultural Research Service; USDI, Bureau of Land Management, Saval Research Project; and the Nevada Agricultural Experiment Station.

The authors thank Debra Palmquist for her considerable effort with the data analysis.

Manuscript accepted 14 July 1987.
The widespread black-tailed jackrabbit (Lepus californicus) exerts a potentially important force upon many rangeland communities. Estimates of the amount of forage consumed by these animals have varied (McAdoo and Young 1980), but the affinity of jackrabbits for cultivated crops is well known, and crop depredation by high jackrabbit populations has been repeatedly documented (Vorhies and Taylor 1933, Sparks 1968, Flinders and Hansen 1972, Fagerstone et al. 1980). Jackrabbits may also compete with domestic livestock for range forage (Vorhies and Taylor 1933, Arnold 1942, Currie and Goodwin 1966, Hansen 1972, Johnson 1979). Thus, the potential economic impacts involved with these lagomorphs are clear. Here we attempt to elucidate factors influencing the extent to which jackrabbits utilize forage on improved rangelands.

Use of established rangeland seedings by black-tailed jackrabbits has been reported in several studies (Flinders and Hansen 1972, Westoby and Wagner 1973, Fagerstone et al. 1980, Westoby 1980). In Utah, Westoby and Wagner (1973) found that grazing of established crested wheatgrass (Agropyron desertorum) stands by the highest density of jackrabbits recorded over a 20 -year period did not cause serious damage. They speculated that grazing by such large populations could harm seedling crested wheatgrass, however, and advised against seeding during peak jackrabbit population years. Similarly, Wagner (1964) suggested that jackrabbits could thwart seeding efforts, especially in small seedings bordering 
unimproved range, by eating emerging seedlings soon after germination.

Observations at various central and northern Nevada locations led us to suspect that seeding establishment may be adversely affected by high abundance of jackrabbits. With that as a working hypothesis, we initiated this study to determine: (1) the extent of jackrabbit use of seedings during the first growing season, (2) whether jackrabbit use varies temporally during the growing season or spatially with distance into a seeding, (3) the effects of seeding size and jackrabbit abundance on intensity of use, and (4) the extent to which jackrabbit abundance differs between native habitat adjacent to a new seeding and similar habitat distantly removed from the seeding.

\section{Study Areas}

We worked on 3 seedings at 2 ranches in central and northern Nevada. All seedings were fenced to exclude livestock grazing.

One study area was at the 71 Ranch in Lamoille Valley, northeast Nevada. This relatively mesic site is on an alluvial fan dominated by Wyoming big sagebrush (Artemisia tridentata wyomingensis). The elevation is approximately $1,950 \mathrm{~m}$ and the area receives an average of $32 \mathrm{~cm}$ annual precipitation. During fall 1981 , 400 ha in this area were plowed to control sagebrush and seeded with Nordan crested wheatgrass (Agropyron desertorum) at 9 $\mathrm{kg} / \mathrm{ha}$. We chose the 71 Ranch seeding because of its relatively large size and purported high jackrabbit population.

Our other study area was at the University of Nevada Gund Research and Demonstration Ranch in Grass Valley, central Nevada. This xeric area is on an alluvial fan dominated by Wyoming big sagebrush at $1,870 \mathrm{~m}$ elevation; it receives an average annual precipiation of $23 \mathrm{~cm}$. During fall 1982, a 50-ha seeding was established by burning sagebrush and planting $9 \mathrm{~kg} /$ ha of Nordan crested wheatgrass. We also sampled a 30-ha big sagebrushdominated plot adjacent to a 30-ha plot which was plowed and seeded to crested wheatgrass during fall 1979. The Gund Ranch jackrabbit population peaked in 1982, but remained fairly high during 1983 (unpublished data, ARS-University of Nevada, Reno).

\section{Methods}

We used monthly counts of jackrabbit pellets as an index of jackrabbit use. The assumption that the number of jackrabbit pellets is proportional to jackrabbit grazing intensity was also made by Westoby and Wagner (1973), who further divided this assumption into 3 auxiliary assumptions, none of which were violated during our study. Jackrabbits on a natural diet produce pellets at a relatively constant rate, primarily while feeding (Lechleitner 1958).

At the 71 Ranch we established transects of $1-\mathrm{m}^{2}$ circular plots at $100-\mathrm{m}$ intervals from the edge ( $5 \mathrm{~m}$ from sagebrush habitat) of the seeding to its midpoint at $400 \mathrm{~m}$ into the seeding's interior. Four groups of 6 plots each were set up along a $300-\mathrm{m}$ transect at each interval. We placed each group of plots at regular $(100-\mathrm{m})$ intervals along the transects, and randomized locations of the 6 plots in each group. Although plots at the Gund Ranch 50-ha seeding were established similarly, fewer transects were required to reach the seeding midpoint at $200-\mathrm{m}$ from the edge.

Jackrabbit pellets were removed from plots at the beginning of study for each area, then counted and removed at monthly intervals. June, July, August, and September counts were taken at the 71 Ranch in 1982 and at the Gund Ranch in 1983.

We also established control transects in sagebrush habitat at both the 71 Ranch and the Gund Ranch. These transects were set up as described above for seeding transects, and were located approximately $1 \mathrm{~km}$ outside of seedings to avoid any edge effect. Pellets were counted on these plots during July, August, and September 1982 at the 71 Ranch, and during August and September 1983 at the Gund Ranch. Pellet counts from these control transects were used as indices of jackrabbit abundance, and comparison of these counts with counts from seedings also provided an indication of the intensity of jackrabbit grazing at each site.

We used the mean number of pellets $/ \mathrm{m}^{2}$ as both an index of seeding use by jackrabbits (pellets $/ \mathrm{m}^{2}$ inside seedings) and as an index of local jackrabbit abundance (pellets $/ \mathrm{m}^{2}$ on control plots outside seedings). We thus assumed that pellet counts outside seedings are indicative of typical jackrabbit densities in the vicinity, and that pellet counts inside seedings are indicative of jackrabbit aggregations from the local population which congregate in seedings for foraging purposes.

A Hartley's F-max text, which indicates homogeneity of variance, showed wide fluctuations in variances of pellet count data. Since variabilty increased directly with increasing means, we used a square-root transformation to stabilize variances, then performed analysis of variance and Duncan's multiple range test on transformed data. All statistical analyses were tested at the .05 and .01 significance levels. We also used analysis of variance on untransformed data, and found that results were identical to those obtained with square-root-transformed data. Results are therefore presented as untransformed data for ease of interpretation, although tests for significance were validated through data transformation.

Finally, we estimated the increase in relative abundance of jackrabbits around a new seeding at the Gund Ranch by comparing counts of jackrabbits seen on line transects in a 30-ha sagebrush plot bordering a newly seeded 30-ha plot with results of similar transects in sagebrush habitat $0.5-5.0 \mathrm{~km}$ outside the seeding. A 2.4-km transect, consisting of eight $300-\mathrm{m}$ segments spaced $50-\mathrm{m}$ apart, was walked each summer in the 30-ha plot 2 to 5 times each year for 5 years (from 1 year before to 4 years after seeding occurred). In sagebrush habitat outside the seeding edge, four to eleven $4.8 \mathrm{~km}$ transects (consisting of four $1.2-\mathrm{km}$ segments) were walked each year for 8 years (1977-1984) overlapping the same time period. We conducted these jackrabbit counts during mid-day when lagomorphs are typically most sedentary (Gross et al. 1974), and thus are less likely to be counted more than once. We compared results from these transects by converting all counts to number of jackrabbits observed per kilometer of transect.

\section{Results and Discussion}

\section{Jackrabbit Use of New Seedings}

Jackrabbit pellet counts were significantly higher $(P \leq .01)$ at the edge of the 71 Ranch seeding than inside (100-400 m) from June through September (Table 1), indicating that use of this large

Table 1. Black-tailed jackrabbit use (pellets/m²) of the 71 Ranch 400-ha crested whentgrass seeding and Gund Ranch 50-ha seeding during the first growing season (June-September, 1982 and 1983, respectively), after establishment.

\begin{tabular}{lccccc}
\hline & \multirow{2}{*}{$\begin{array}{c}\text { Distance into } \\
\text { Study Area }\end{array}$} & \multicolumn{4}{c}{ Jackrabbit pellets $/ \mathrm{m}^{2}$} \\
\cline { 4 - 6 } & seeding $(\mathrm{m})$ & June & July & August & September \\
\hline 71 Ranch & Edge & $8.2 \mathrm{c}^{1}$ & $16.3 \mathrm{~b}$ & $14.6 \mathrm{~b}$ & $23.6 \mathrm{a}$ \\
& 100 & $3.8 \mathrm{~d}-\mathrm{g}$ & $5.7 \mathrm{c}-\mathrm{f}$ & $6.5 \mathrm{c}-\mathrm{e}$ & $7.0 \mathrm{c}-\mathrm{d}$ \\
& 200 & $3.7 \mathrm{e}-\mathrm{g}$ & $2.7 \mathrm{f}-\mathrm{h}$ & $5.3 \mathrm{c}-\mathrm{f}$ & $4.8 \mathrm{c}-\mathrm{f}$ \\
& 300 & $1.0 \mathrm{~g}-\mathrm{h}$ & $1.5 \mathrm{~g}-\mathrm{h}$ & $4.8 \mathrm{c}-\mathrm{f}$ & $8.9 \mathrm{c}$ \\
& 400 (midpoint) & $0.5 \mathrm{~h}$ & $1.0 \mathrm{~g}-\mathrm{h}$ & $7.0 \mathrm{c}-\mathrm{c}$ & $4.5 \mathrm{c}-\mathrm{f}$ \\
& Sagebrush & & & & \\
& Control & - & $14.8 \mathrm{~b}$ & $14.3 \mathrm{~b}$ & $14.9 \mathrm{~b}$ \\
Gund Ranch & Edge & $28.8 \mathrm{bc}$ & $22.3 \mathrm{bc}$ & $26.5 \mathrm{bc}$ & $32.3 \mathrm{~b}$ \\
& 100 & $21.0 \mathrm{bc}$ & $23.5 \mathrm{bc}$ & $24.5 \mathrm{bc}$ & $46.9 \mathrm{a}$ \\
& 200 (midpoint) & $20.1 \mathrm{c}$ & $25.0 \mathrm{bc}$ & $25.9 \mathrm{bc}$ & $49.8 \mathrm{a}$ \\
& Sagebrush & & & & \\
& Control & - & - & $8.9 \mathrm{~d}$ & $9.0 \mathrm{~d}$ \\
\hline
\end{tabular}

'Specific to each ranch, means followed by the same letter are not significantly different at the .01 level of probability as determined by Duncan's multiple range test. 
seeding was concentrated near the edge. Jackrabbit use increased significantly $(P \leq .01)$ toward the middle during August and September, however, compared with June and July. In fact, use was almost 9 times greater in September $\left(8.9\right.$ pellets $\left./ \mathrm{m}^{2}\right)$ than in June $(1.0$ pellets $/ \mathrm{m})$ at $300 \mathrm{~m}$ into the seeding. Table 1 also shows there was a corresponding increase $(P \leq .01)$ in late summer use of the seeding edge, so the edge was the most intensively used portion at all times. Mean pellet counts on the 71 Ranch control plots were statistically similar $(P>.01)$ for July, August, and September, respectively. These pellet counts generally exceeded those recorded in the seeding. Only during September at the seeding edge were seeding counts higher $(P \leq .01)$ than sagebrush habitat control counts.

The smaller Gund Ranch seeding received fairly uniform jackrabbit use from the edge to the $200-\mathrm{m}$ midpoint until September, when pellet counts were significantly higher $(P \leq .01)$ at 100 and 200 $m$ than at the edge (Table 1). Combined results from all months showed no significant difference $(P>.05)$ between jackrabbit use at the edge, at $100 \mathrm{~m}$, and at $200 \mathrm{~m}$ inside the seeding. Combining all distances, mean pellet counts were similar $(P>.05)$ for June, July, and August $\left(23.3,23.6\right.$, and 25.7 pellets $/ \mathrm{m}^{2}$, respectively) but the September mean ( 43.0 pellets $\left./ \mathrm{m}^{2}\right)$ was significantly higher $(P \leq .01)$ than earlier counts. Mean pellet counts on the Gund Ranch control plots were significantly lower $(P \leq .01)$ in both August and September than those measured at each distance inside the seeding during these months (Table 1), indicating substantial use of the seeding by jackrabbits.

Our assumption that pellet counts provided reasonable indices of jackrabbit grazing intensity (use) is supported by comparison of our results for the 400-ha 71 Ranch seeding and 50-ha Gund Ranch seeding with those reported by Roundy et al. (1985), who measured plant utilization on these 2 seedings during the same time period. Corresponding with our higher pellet counts at the edge of the 71 Ranch seeding, Roundy et al. (1985) reported significantly higher utilization of crested wheatgrass seedlings (by weight) at the edge than at the center. At the Gund Ranch seeding, both pellet counts and plant utilization data showed similar patterns of grazing intensity from the seeding edge to its midpoint. The general increase in jackrabbit use of both seedings from early to late summer was also documented with both pellet count and plant utilization data.

We also assumed relative homogeneity of vegetation for interpretation of jackrabbit pellet counts at varying distances into the seedings. Seedling establishment and survival on jackrabbitexclosure plots were statistically similar between the edge and center for both the 71 Ranch and Gund Ranch seedings (Roundy et al. 1985). Vegetation data collected at these 2 seedings showed that seedling establishment was well above the minimum considered to be good establishment for sites in this precipitation range (Roundy et al. 1985).

The inverse relationship between jackrabbit use and midpoint distance, as observed at the large 71 Ranch seeding, was perhaps expected, since jackrabbits seem to frequent feeding sites that allow detection from moderate distances but which do not render them conspicuous from greater distance (Hansen and Flinders 1969). Even though these animals are highly cursorial, relying on speed more than cover in evading predators, they apparently have an innate tendency for remaining near protective cover. Fagerstone et al. (1980) suggested that cultivated crops (including crested wheatgrass) are particularly vulnerable to jackrabbit damage because adjacent unimproved rangeland provides daytime resting areas from which jackrabbits move to forage in crop areas at night. Because of the affinity of jackrabbits for protective cover, we believe that distance to a seeding's midpoint from rangeland edges is superior to seeding size, per se, as an indicator of potential jackrabbit use. Although midpoint distance is obviously a function of seeding size, it is also a property of the geometry of seedings. We suggest extent of jackrabbit depredation is positively related to the ratio of seeding perimeter to seeding area, and therefore, circular

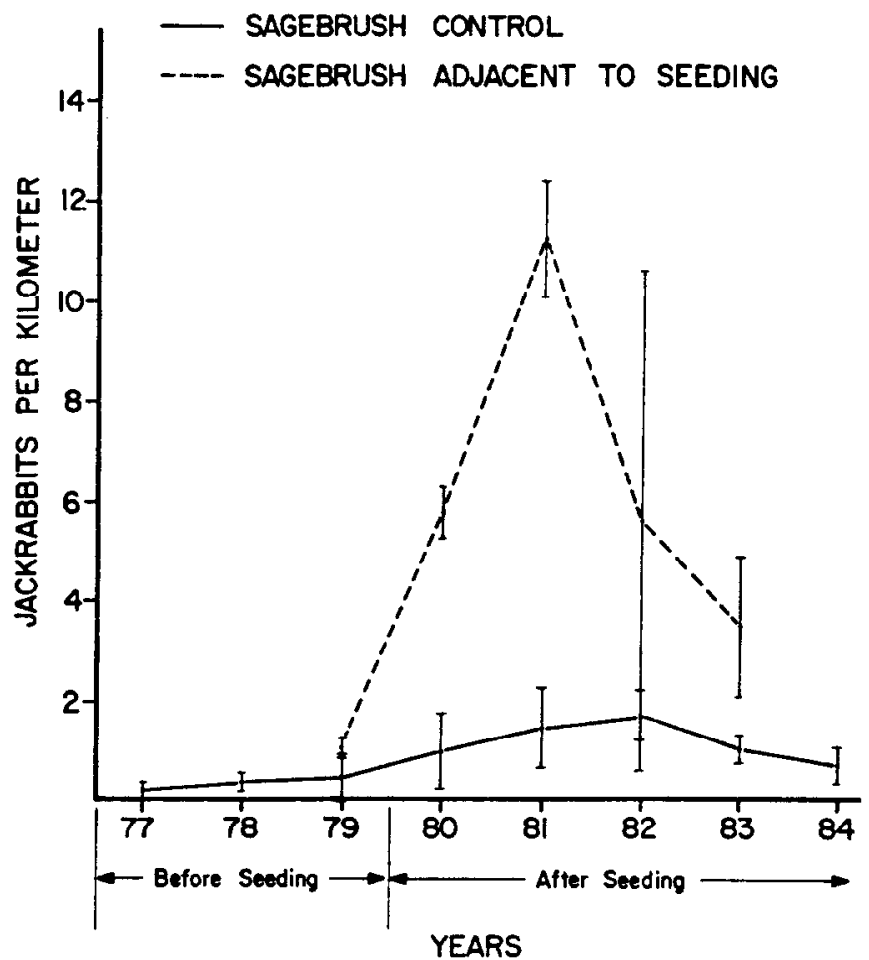

Fig. 1. Relative abundance of jackrabbits (number observed per linear kilometer $\pm S E$ ) in sagebrush habitat within $0.2 \mathrm{~km}$ of a new crested wheatgrass seeding edge, and in sagebrush control habitat $0.5-5.0 \mathrm{~km}$ away from seeding (Gund Ranch, Grass Valley, Nevada).

seedings are optimal for minimizing jackrabbit damage. Westoby and Wagner (1973) similarly concluded that large circular seedings would reduce jackrabbit grazing pressure.

Fagerstone et al. (1980) found that jackrabbits foraged most heavily on the edge of crops bordering unimproved rangeland. On a large (2,100-ha), old crested wheatgrass seeding Westoby and Wagner (1973) found that jackrabbit use was concentrated in a $300-\mathrm{m}$ band around its perimeter. Our results from the 400-ha 71 Ranch seeding are similar, although even at $100 \mathrm{~m}$ into the seeding jackrabbit use was significantly lower than at the edge. This relationship did not, however, occur with the smaller Gund Ranch seeding. The uniformly heavy jackrabbit use from edge to middle of this seeding seems to support Wagner's (1964) speculation that jackrabbits could harm seedling crested wheatgrass on small seedings adjacent to unimproved range. Apparently, however, no permanent damage has resulted to the Gund Ranch seeding from heavy jackrabbit grazing. Roundy et al. (1985) showed that in spite of 70 jackrabbit utilization of seedlings occurring throughout the Gund Ranch seeding, seedling establishment and survival were not significantly affected in the absence of other deleterious factors, such as drought or restricted plant root zone. Larger jackrabbit population densities, however, may indeed cause serious damage to newly established small seedings.

The increased use of seedings during late summer could have been the result of augmentation of the local jackrabbit population with juveniles and/or a progressive decrease in native forage availability or quality. Maximum use of seedings occurred during late summer when rangeland forage was less abundant and possibly less palatable than seedlings of crested wheatgrass. From research conducted in a southern Idaho location where crops bordered rangeland, Fagerstone et al. (1980) suggested that crested wheatgrass was a highly preferred food of jackrabbits. Flinders and Hansen (1972) and Fagerstone et al. (1980) further suggested that jackrabbits preferred plants which were in prereproductive or early 
reproductive stages of growth. Plants in such stages are typically at peak nutritive value, having high water and crude protein content.

Jackrabbit use was significantly higher $(P \leq .01)$ at the Gund Ranch seeding than at the larger 71 Ranch seeding for all comparable distance intervals pooled across months and for all sampling times pooled across comparable distances. We acknowledge, however, that such comparisons are confounded as a result of temporal and spatial heterogeneity (i.e., comparisons between ranches may be misleading, due to the fact that seedings were established in different years and different locations). The higher seeding use at the Gund Ranch did not reflect a larger jackrabbit population, as might be expected. On the contrary, the jackrabbit abundance index (pellet densities outside seedings, Table 1) was significantly higher $(P \leq .01)$ at the 71 Ranch. We believe our sagebrush habitat pellet counts at the Gund Ranch and 71 Ranch provided reasonable indices of jackrabbit abundance. In a companion study, jackrabbit density estimates obtained from walked line transects in sagebrush habitats at the 71 Ranch in 1982 and the Gund Ranch in 1983 were 2.9 and 1.4 jackrabbits/ha, respectively (Roundy et al. 1985)-a ratio of 2.1 to 1 . Our pellet-count indices are relatively similar, having a 71 Ranch to Gund Ranch abundance ratio of 1.7 to 1 . We cautiously infer that jackrabbit abundance is not as important in determining potential grazing intensity as intuition would suggest.

We propose that the disparity between jackrabbit use of the 71 Ranch and Gund Ranch seedings was the result of differences in sensitivity of jackrabbits to predation risk (as related to seeding size) and/or differential productivity of seedings. Although jackrabbits tend to feed in areas with high grass cover (Johnson and Anderson 1984), they also require canopy cover, which presumbly provides protection from direct sunlight and predators (Fautin 1946, Lechleitner 1954). Thus, the greater jackrabbit use of the Gund Ranch seeding was possibly the result of shrub cover accessibility being an inverse function of seeding size. Similarly, the sharp drop in the use of the 71 Ranch seeding at $100 \mathrm{~m}$ from the edge may have been at least partially a jackrabbit response to predation risk.

Roundy et al. (1985) estimated herbaceous forage production for the 71 Ranch seeding to be $186 \mathrm{~kg} / \mathrm{ha}$, compared to $333 \mathrm{~kg} / \mathrm{ha}$ of herbaceous forage in nearby sagebrush habitat, a ratio of 0.56 to 1. Comparatively, they estimated $636 \mathrm{~kg} / \mathrm{ha}$ for the Gund Ranch seeding, and $12 \mathrm{~kg} / \mathrm{ha}$ in adjacent sagebrush habitat, a ratio of 53.0 to 1 . To generalist herbivores such as jackrabbits (Westoby 1974), the forage availability of the Gund Ranch seeding relative to surrounding sagebrush habitat surpasses the 71 Ranch seeding by nearly 2 orders of magnitude. This difference in forage availability would also explain the consistently high use of the Gund Ranch seeding each month as compared with use of nearby sagebrush.

\section{Jackrabbit Abundance near a New Seeding}

Results of line transects showed a high abundance of jackrabbits occurred in sagebrush habitat adjacent to a new 30-ha crested wheatgrass seeding at the Gund Ranch. During summer 1979 (before seeding establishment) jackrabbit abundance in sagebrush within $0.2-\mathrm{km}$ of the area to be seeded was similar $(P>.05)$ to abundance in other sagebrush habitat 0.5 to $5.0-\mathrm{km}$ from the seeding (Fig. 1). During 1981, however, 2 years after seeding establishment, jackrabbit abundance adjacent to the seeding was nearly 9 times higher ( 11.3 vs. 1.3 jackrabbits $/ \mathrm{km})$. This high jackrabbit concentration indicates the seeding was an important food source. Although there are several reasons for the often patchy distributions of these animals, food shortage (Woodbury 1955) and presence of cultivated crops (Fagerstone et al. 1980) are 2 potential causative factors. The decline in jackrabbit abundance near the seeding after 1981 (Fig. 1) may have been caused by a decrease in relative forage quality with time. This decline occurred as jackrab- bit abundance away from the seeding was still rising (Fig. 1), concurrent with a cyclic upswing which was verified for the Grass Valley area during this time (unpublished data, ARS-University of Nevada, Reno).

\section{Conclusions}

We have shown that jackrabbit use of new crested wheatgrass seedings is variable according to seeding size, distance into seeding at which use is measured, and time (month) of use. Because our results were clouded by the temporal and spatial heterogeneity of the study sites as well as differences in seeding geometry, however, we were not able to discern a clear relationship between jackrabbit abundance and use of new seedings.

We have also proposed that relative food availability (which constitutes a benefit) and/or predation risk (which constitutes a cost) may influence jackrabbit use of seedings. These hypotheses are not mutually exclusive: both could operate simultaneously. If both were operative, it would suggest that jackrabbits balance cost/benefit tradeoffs, which is a basic tenet of optimal foraging theory (Krebs 1978). Such a tradeoff would occur if jackrabbits were to minimize risk by foraging near cover when such areas provide sufficient food, but switch foraging habitats when nearby open areas reach some threshold increment of extra profitability and benefits outweigh costs. The fact that jackrabbit pellet counts remained rather consistent on the sagebrush control plots, while pellet counts on seedings increased significantly from early to late summer suggests that such a switching phenomenon did indeed occur. If jackrabbits are balancing costs and benefits, then knowledge of the relationship between thresholds of risk (e.g., predator densities) and of food-patch profitability necessary to cause a foraging-habitat switch will aid in predicting the probability of successfully establishing a crested wheatgrass seeding. We encourage such detailed studies of black-tailed jackrabbit foraging and attempts to integrate theoretical and applied science.

\section{Literature Cited}

Arnold, J.F. 1942. Forage consumption and preferences of experimentally fed Arizona and antelope jackrabbits. Univ. Arizona Agr. Exp. Sta. Tech. Bull. 98:51-86.

Currie, P.O., and D.L. Goodwin. 1966. Consumption of forage by blacktailed jackrabbits on salt-desert ranges of Utah. J. Wildl. Manage. 30:304-311.

Fagerstone, K.A., G.K. Lavoie, and R.E. Grifnth, Jr. 1980. Black-tailed jackrabbit diet and density on rangeland and near agricultural crops. $J$. Range Manage. 33:229-233.

Fautin, R.W. 1946 Biotic communities of the northern desert shrub biome in western Utah. Ecol. Monogr. 16:251-310.

Flinders, J.T., and R.M. Hansen. 1972. Diets and habitats of jackrabbits in northeastern Colorado. Colorado State Univ. Range Sci. Dep. Sci. Ser. No. 12.

Gross, J.E., L.C. Stoddart, and F.H. Wagner. 1974. Demographic analysis of a northern Utah jackrabbit population. Wildl. Monogr. No. 40.

Hansen, R.M. 1972. Estimation of herbage intake from jackrabbit feces. J. Range Manage. 25:468-471.

Hansen, R.M., and J.T. Flinders. 1969. Food habits of North American hares. Colorado State Univ. Range Sci. Dep. Sci. Ser. No. 1

Johnson, M.K. 1979. Foods of primary consumers on cold desert shrubsteppe of southern Colorado. J. Range Manage. 32:365-368.

Johnson, R.D., and J.E. Anderson. 1984. Diets of black-tailed jackrabbits in relation to population density and vegetation. J. Range Manage. 37:79-83.

Krebs, J.R. 1978. Optimal foraging: decision rules for predators. p. 23-63. In: J.R. Krebs and N.B. Davies (eds.), Behavioural Ecology: An Evolutionary Approach. Blackwell Sci. Publ., Oxford.

Lechleitner, R.R. 1954. Movements, density, and mortality in a blacktailed jackrabbit population. J. Wildl. Manage. 22:371-384. 
Lechleitner, R.R. 1958. Certain aspects of behavior of the black-tailed jackrabbit. Amer. Midl. Natur. 60:145-155.

McAdoo, J.K., and J.A. Young. 1980. Jackrabbits. Rangelands 2:135-138. Roundy, B.A., G.J. Cluff, J.K. McAdoo, and R.A. Evans. 1985. Effects of jackrabbit grazing, clipping, and drought on crested wheatgrass seedlings. J. Range Manage. 38:551-555.

Sparks, D.R. 1968. Diet of black-tailed jackrabbits on sandhill rangeland in Colorado. J. Range Manage. 21:203-208.

Vorhies, C.T., and W.P. Taylor. 1933. The life historics and ecology of jackrabbits. Lepus alleni and Lepus californicus spp., in relation to grazing in Arizona. Univ. Arizona Agr. Exp. Sta. Tech. Bull. 49:471-587.
Wagner, F.H. 1964. The jackrabbit in its western habitat. Utah Farm and Home Sci. 2:64-65, 78-79.

Westoby, M. 1974. An analysis of diet selection by large generalist herbivores. Amer. Natur. 108:290-304.

Westboby, M. 1980. Black-tailed jackrabbit diets in Curlew Valley, northern Utah. J. Wildl. Manage. 44:942-948.

Westoby, M., and F.H. Wagner. 1973. Use of a crested wheatgrass seeding by black-tailed jackrabbits. J. Range Manage. 26:349-352.

Woodbury, A.M. 1955. Ecology of the Great Salt Lake Desert. I. An Annual cycle of the desert jackrabbit. Ecology 36:353-356. 